\title{
Accountability of Corporate Health Rating in Improving Corporate Performance
}

\author{
Eni Wuryani \\ Universitas Negeri Surabaya \\ Surabaya, Indonesia \\ eniwuryani@unesa.ac.id
}

\begin{abstract}
The purpose of the study to analyze the accountability of corporate health rating in improving the Company Performance. Assessment of the level of health conducted under the rules of BUMN. This research was conducted on one of the regional companies in East Java. Research data in the form of financial statements in the year 2016 -2017. The performance of Regional companies in East Java during 2016 - 2017 has a good performance. Good performance is seen in health assessments conducted by self-assessment with healthy criteria. For 2 years the regional company has a good performance with a healthy level with healthy associates with AA criteria.
\end{abstract}

Keywords-accountability; health rating; corporate performance

\section{INTRODUCTION}

A regional company is a company incorporated under a Regional Regulation whose capital is not subdivided into shares, for all or partly of separated Regional property. The Regional Government health rating refers to the BUMN regulation on Health Level Peniliation. Assessment of health level in class to be healthy, less healthy, and unhealthy. The local government as the owner of the company will evaluate the performance of the regional companies. Evaluations made through the first quarter report, second quarter financial reports, third quarter financial reports, and financial statements.

Accountability carried out by Regional companies is the responsibility as one of the public sector organizations. Accountability from managers of public sector organizations to those who have interests and the community. Based on agency theory Jensen and Meckling [1], the relationship between the principal (owner) and agent (management) is responsible to the local government. Regional Companies as management (agents) carries out operational activities. Accountability local governments must create a more transparent and accountable financial management system. Accountability by paying attention to justice, compliance and benefits for the community.

\section{LITERATURE REVIEW}

\section{A. Contingency theory}

Based on contingency theory that influences the development and function of an organization include size, environmental uncertainty, technology and environmental pressure [2]. Contingency theory identifies the relationship between internal and external characteristics of the organization and management capacity Contingency or limitation of organizational structure in terms of training, specialization, differentiation and bureaucratization [3]. Contingency theory is based on the premise that there is no proper accounting system that applies equally to all organizations in all situations " [4]. There is no universal model of control and accounting systems that are suitable for and applicable to all organizations and circumstances [5]. Organizations will have to adopt new accounting practices that seek better adjustment between administrative systems and their contingency factors [5]. The design of a new accounting system will depend on the capacity of organizations that recognize and adapt to change as a function of external and internal factors. Research that uses a contingency perspective in explaining reforms in public sector management and accounting, investigates specifically the introduction of new systems that measure and manage performance, as well as new accounting and reporting systems [5].

\section{B. Accountability}

The performance of Corporate Social Responsibility (CSR) correlates with financial performance. CSR performance synergizes with potential disclosure regulations for content and credibility of corporate accountability reporting. Payment for Performance results in improvements in internal accountability measures, through increasing relations and communication between stakeholders who are given incentives at various levels of the system and increasing the autonomy of fund providers. Payment for Performance has a more limited effect on external accountability.

Belal, et al. [6] argue that companies must report to improve accountability. Achieving accountability requires political will and high costs. The experience of learning initiatives shows accountants' important support for facilitative reforms to be a useful strategy.

Individual accountability is the belief that everyone will be responsible for their performance. Individual accountability occurs when the performance of each individual is assessed and the results are given back to groups and individuals. Kaynak and Avci [7] explain that accountability in logistics services has a positive effect on buyer confidence in three dimensions such as logistical service accountability, financial accountability, and marketing accountability. Organizations 
use funds correctly and in an authorized manner. Organizations have clear operational goals to be achieved every year. Organizations have a strategy for regular and effective communication with all stakeholders such as the public, customers, and funders.

Important elements in the new Public Management (NPM) on performance measurement that focuses on results. Accountability depends on the main elements, especially motivation and intentions, organizational accountability practices. Accountability can serve various stakeholders. The normative model of accountability theory includes functional, communitarian, social, holistic and downward accountability primarily as an effort to understand partial accountability of the company.

Accountability can reduce manipulation and violations in money politics. Accountability in the financial and nonfinancial context. Accountability can prevent political actors from committing money politics and corruption. Public trusts in government is an important factor. Ethical accountability has an influence on trust. Accountability and public believe that local government and central government need synchronization.

\section{Financial Statement Infomation}

Financial reports are used by organizations for decision making. Motivation for organizational change requires efforts to improve efficiency and effectiveness. Organizational change is influenced by external and internal factors. External factors include government, professional groups, technology, and customers. Financial reports are used by organizations for decision making. Internal factors include the need for efficiency, professionalism, changes in the dynamics of autonomy, the size and complexity of the organization, and the search for strategies. Accounting systems are also needed in organizational change. Factors that can influence change include accounting and reporting systems, usefulness of financial information, institutional and legal pressures, lack of understanding of the accrual basis, lack of human resources and resistance to change.

Some factors are directly related to individual characteristics and attitudes of decision makers, others are the result of certain institutional standards of each organization and others concerning external circumstances. Skills, knowledge and experience concepts and financial management tools are factors that are related to the individual characteristics of decision makers [8]. Decision making is based on the level of use of financial reporting data [9]. The potential benefits of data for users (relevance, conformity with expectations) are an understanding of financial information.

\section{Assessment of the Company's Regional Health Level}

This rating is based on the Decree of State-Owned Enterprises Number: KEP-100 / MBU / 2002 on Assessment of Health Level of State-Owned Enterprises.

The Health Rating is classified into:

a. HEALTHY, consisting of:
AAA if the total of Scores (TS) is greater than 95

AA if $80<\mathrm{TS}<=95$

A if $65<\mathrm{TS}<=80$

b. LESS OF HEALTH, which consists of:

$\mathrm{BBB}$ if $50<\mathrm{TS}<=65$

$\mathrm{BB}$ if $40<\mathrm{TS}<=50$

$\mathrm{B}$ if $30<\mathrm{TS}<=40$

c. NOT HEALTHY, which consists of:

CCC if $20<\mathrm{TS}<=30$

$\mathrm{CC}$ if $10<\mathrm{TS}<=20$

C when TS $<=10$

The soundness of the BUMN is determined based on an assessment of the Company's performance for the relevant fiscal year which includes assessment:

a. Financial aspect.

b. Operational Aspects.

c. Aspects of Administration.

Assessment of BUMN Level of Health in accordance with this decision shall be applied only to BUMN if the result of an accountant's examination of the company's annual financial statements is stated with "Unqualified" qualification or "Fair with Exception" qualification from a public accountant or Finance and Development Supervisory Board. BUMN is stipulated annually in the ratification of annual report by General Meeting of Shareholders or Minister of BUMN for Public Enterprises (PERUM).

\section{METHOD}

This study uses a quantitative descriptive approach. This study uses secondary data in the form of financial reports on one of the Regional companies in East Java. The Financial Statements were analyzed in 2016 to 2017. In this study only conducted an assessment of the soundness of the company based on financial aspects. 
IV. RESULT AND DISCUSSION

TABLE I. REPORT ON FINANCIAL POSITION FOR 2016 - 2017

\begin{tabular}{|c|c|c|c|c|}
\hline \multirow{3}{*}{$\begin{array}{c}\text { INFOR } \\
\text { MATION }\end{array}$} & AUDIT & AUDIT & \multirow{3}{*}{$\begin{array}{c}\text { the increase/ } \\
\text { decrease } \\
\text { a-b }\end{array}$} & \multirow{3}{*}{$\begin{array}{c}\% \\
(\mathbf{a}- \\
\text { b)/b }\end{array}$} \\
\hline & 2017 & 2016 & & \\
\hline & $\mathbf{A}$ & B & & \\
\hline \multicolumn{5}{|l|}{ ASSET } \\
\hline $\begin{array}{l}\text { Current } \\
\text { Asset }\end{array}$ & 14.973 .745 .241 & 14.269 .402 .442 & 704.342 .799 & 4.70 \\
\hline $\begin{array}{l}\text { Non- } \\
\text { Current } \\
\text { Assets }\end{array}$ & 27.031 .693 .679 & 25.267 .225 .216 & 1.764 .468 .463 & 6.53 \\
\hline $\begin{array}{l}\text { Total } \\
\text { Assets }\end{array}$ & 42.005 .438 .920 & 39.536 .627 .658 & 2.468 .811 .262 & 5.88 \\
\hline \multicolumn{5}{|l|}{$\begin{array}{l}\text { LIABILITY } \\
\text { AND } \\
\text { EQUITY }\end{array}$} \\
\hline \multicolumn{5}{|l|}{ LIABILITY } \\
\hline $\begin{array}{l}\text { Short } \\
\text { Term } \\
\text { Liabilities }\end{array}$ & 4.092 .540 .775 & 3.230 .625 .067 & 861.915 .708 & 21.06 \\
\hline $\begin{array}{l}\text { Long- } \\
\text { Term } \\
\text { Liabilities }\end{array}$ & 4.818 .365 .563 & 5.124 .599 .219 & (306.233.656) & (6.36) \\
\hline $\begin{array}{l}\text { Total } \\
\text { Liability }\end{array}$ & 8.910 .906 .338 & 8.355 .224 .286 & 555.682 .052 & 6.24 \\
\hline EQUITY & & & & \\
\hline $\begin{array}{l}\text { Total } \\
\text { Equity }\end{array}$ & 33.094 .532 .582 & 31.181 .403 .371 & 1.913.129.211 & 5.78 \\
\hline $\begin{array}{l}\text { Total } \\
\text { Liability } \\
\text { and } \\
\text { Equity }\end{array}$ & 42.005 .438 .920 & 39.536 .627 .657 & 2.468 .811 .263 & 5.88 \\
\hline
\end{tabular}

TABLE II. PROFIT AND LOSS STATEMENT FOR 2016-2017

\begin{tabular}{|l|c|c|c|c|}
\hline & AUDIT & AUDIT & $\begin{array}{c}\text { the increase/ } \\
\text { decrease }\end{array}$ & \% \\
\cline { 2 - 5 } $\begin{array}{l}\text { INFOR } \\
\text { MATION }\end{array}$ & $\mathbf{2 0 1 6}$ & $\mathbf{2 0 1 7}$ & $\mathbf{a - b}$ & $\begin{array}{c}\mathbf{( a -} \\
\mathbf{b}) / \mathbf{b}\end{array}$ \\
\cline { 2 - 5 } & $\mathbf{A}$ & $\mathbf{B}$ & & \\
\hline $\begin{array}{l}\text { Sales } \\
\text { And } \\
\text { Operating } \\
\text { Revenues }\end{array}$ & 20.279 .841 .734 & 18.562 .643 .436 & 1.717 .198 .298 & 9.25 \\
\hline $\begin{array}{l}\text { Cost of } \\
\text { Sales and } \\
\text { Direct } \\
\text { Expenses }\end{array}$ & 11.607 .081 .408 & 10.687 .674 .980 & 919.406 .428 & 8.60 \\
\hline $\begin{array}{l}\text { Gross } \\
\text { profit }\end{array}$ & 8.672 .760 .326 & 7.874 .968 .456 & 797.791 .870 & 10.13 \\
\hline $\begin{array}{l}\text { Operating } \\
\text { expenses }\end{array}$ & 4.369 .408 .568 & 3.579 .554 .509 & 789.854 .059 & 22.07 \\
\hline $\begin{array}{l}\text { Operating } \\
\text { profit }\end{array}$ & 4.303 .351 .758 & 4.295 .413 .947 & 7.937 .811 & 0.18 \\
\hline $\begin{array}{l}\text { Other } \\
\text { income }\end{array}$ & & & & 8.98 \\
\hline $\begin{array}{l}\text { Financial } \\
\text { interest } \\
\text { income }\end{array}$ & 520.022 .639 & 477.154 .225 & 42.868 .414 & 8.98 \\
\hline $\begin{array}{l}\text { Total } \\
\text { Other } \\
\text { Income }\end{array}$ & 520.022 .639 & 477.154 .225 & 42.868 .414 & 8.98 \\
\hline $\begin{array}{l}\text { Profit } \\
\text { before } \\
\text { Income } \\
\text { Tax }\end{array}$ & 4.823 .374 .397 & 4.772 .568 .172 & 50.806 .225 & 1.06 \\
\hline
\end{tabular}

\begin{tabular}{|l|l|l|l|l|} 
Expense & & & & \\
\hline $\begin{array}{l}\text { Income } \\
\text { Tax } \\
\text { Expense }\end{array}$ & 1.043 .518 .864 & 1.016 .417 .625 & 27.101 .239 & 2.67 \\
\hline $\begin{array}{l}\text { Current } \\
\text { year } \\
\text { profit }\end{array}$ & 3.779 .855 .533 & 3.756 .150 .547 & 23.704 .986 & 0.63 \\
\hline
\end{tabular}

TABLE III. FINANCIAL RATIO

\begin{tabular}{|c|c|c|c|}
\hline NO & INFORMATION & AUDIT & AUDIT \\
\hline & & 2017 & 2016 \\
\hline & & $\%$ & $\%$ \\
\hline I & Liquidity Ratio & & \\
\hline 1 & Current Ratio & 366 & 442 \\
\hline 2 & Cash Ratio & 282 & 344 \\
\hline 3 & Quick Ratio & 328 & 394 \\
\hline II & Profitability Ratio & & \\
\hline 1 & Gross Profit Margin & 43 & 42 \\
\hline 2 & Operating Profit Margin & 21 & 23 \\
\hline 3 & Net Profit Margin & 9 & 10 \\
\hline 4 & Earning Power of Total Investment & 11 & 12 \\
\hline 5 & Return On Invesment (ROI) & 18 & 19 \\
\hline 6 & Return on Equity (ROE) & 25 & 25 \\
\hline III & Solvency Ratio & & \\
\hline 1 & Debt to Aset Rasio (DAR) & 21 & 21 \\
\hline 2 & Debt to equity ratio (DER) & 27 & 27 \\
\hline IV & Activity Ratio & & \\
\hline 1 & Total Aset Turn Over (TATO) & 48 & 47 \\
\hline 2 & WCTO & 589 & 586 \\
\hline 3 & Fixed Aset Turn Over (FATO) & 75 & 73 \\
\hline 4 & Collection Period & 34 & 32 \\
\hline 5 & Inventory Turn Over & 0 & 0 \\
\hline 6 & Operational Costs of operating income & 57 & 58 \\
\hline 7 & Total Own Capital to Total Assets & 79 & 79 \\
\hline
\end{tabular}

TABLE IV. ILLUSTRATION OF HEALTH LEVEL, YEAR 2016

\begin{tabular}{|c|c|c|c|c|}
\hline NO & INFORMATION & WEIGHT & VALUE 2016 & SCORE 2016 \\
\hline & & & AUDIT & AUDIT \\
\hline & $\begin{array}{l}\text { FINANCIAL } \\
\text { ASPECT }\end{array}$ & & & \\
\hline 1 & R OE & 20 & 25 & 20 \\
\hline 2 & R O I & 15 & 19 & 13.5 \\
\hline
\end{tabular}




\begin{tabular}{|c|c|c|c|c|}
\hline 3 & Cash Ratio & 5 & 344 & 5 \\
\hline 4 & Current Ratio & 5 & 442 & 5 \\
\hline 5 & $\begin{array}{c}\text { Collection Period } \\
\text { (CP) }\end{array}$ & 5 & 32 & 4 \\
\hline 6 & $\begin{array}{c}\text { Inventory Turn } \\
\text { Over }\end{array}$ & 5 & 0 & 5 \\
\hline 7 & $\begin{array}{c}\text { Total Aset Turn } \\
\text { Over (TATO) }\end{array}$ & 5 & 47 & 2.5 \\
\hline 8 & $\begin{array}{c}\text { Total Own Capital } \\
\text { to Total Assets }\end{array}$ & 10 & 79 & 7.5 \\
\hline & Total & 70 & & 62.5 \\
\hline
\end{tabular}

This health level assessment is based on the Decree of the State-Owned Enterprise Number: KEP - 100 / MBU / 2002 about the Rating of the Health of State-Owned Enterprises. Assessment aspects based on Article 3 Number: KEP - 100 / MBU / 2002 assessment there are 3 aspects, namely Financial Aspects, Operational Aspects and Administrative Aspects. In this analysis only analyze the Financial Aspect based on financial reports from Regional Company.

Table IV Assessment results based on financial aspects In 2017 Regional Company reached a score of 63, the achievement of financial aspects has a value of 90. Regional Company in East Java is categorized as Healthy with AA criteria

TABLE V. ILLUSTRATION OF HEALTH LEVEL， YEAR 2017

\begin{tabular}{|c|c|c|c|c|}
\hline NO & INFORMATION & WEIGHT & VALUE 2017 & $\begin{array}{c}\text { SCORE } \\
\mathbf{2 0 1 7}\end{array}$ \\
\hline & $\begin{array}{c}\text { FINANCIAL } \\
\text { ASPECT }\end{array}$ & & AUDIT & AUDIT \\
\hline 1 & R O E & 20 & 25 & 20 \\
\hline 2 & R O I & 15 & 18 & 13.5 \\
\hline 3 & Cash Ratio & 5 & 282 & 5 \\
\hline 4 & $\begin{array}{c}\text { Current Ratio } \\
\text { (CP) }\end{array}$ & 5 & 366 & 5 \\
\hline 5 & $\begin{array}{c}\text { Collection Period } \\
\text { (CP) }\end{array}$ & 5 & 34 & 4.5 \\
\hline & $\begin{array}{c}\text { Inventory Turn } \\
\text { Over }\end{array}$ & 5 & 0 & 5 \\
\hline
\end{tabular}

\begin{tabular}{|c|c|c|c|c|}
\hline 7 & $\begin{array}{c}\text { Total Aset Turn } \\
\text { Over (TATO) }\end{array}$ & 5 & 48 & 2,5 \\
\hline 8 & $\begin{array}{c}\text { Total Own Capital } \\
\text { to Total Assets }\end{array}$ & 10 & 79 & 7,5 \\
\hline & Total & 70 & 852 & 63 \\
\hline
\end{tabular}

Table V Assessment results based on financial aspects In 2017 Regional Company reached a score of 63, the achievement of financial aspects has a value of 90. Regional Company in East Java is categorized as Healthy with AA criteria

\section{CONCLUSION}

For 2 year-experience profits, The local company's performance based on the health rating of the company has a healthy value. Based on ownership of local companies owned by local government, the performance of local companies experienced profitable earnings for local government, because there is a contribution that will be accepted by the local government. Based on the ownership of regional companies, the benefits gained will contribute to local revenues. For 2 years the regional company has a good performance with a healthy level with healthy associates with AA criteria

\section{ACKNOWLEDGMENT}

Our thanks go to the East Java Province Regional Secretariat, the Economic Administration Bureau, which has provided regional-level financial statements of the Company in 2016-2017

\section{REFERENCES}

M. C. Jensen and W. H. Meckling, "Theory of the Firm: Managerial Behavior, Agency Costs and Ownership Structure," Journal of Financial Economics, vol. 3, pp. 305-360, October 1976.

A. P. Thomas, Towards a Contingency Theory of Corporate Financial Reporting System vol. 4, 1991.

M. Covaleski, A. M. W. Dirsmith, and S. Samuel, "Managerial accounting research: the contributions of organizational and sociological theories," Journal of Management Accounting Research, pp. 1-36, 1996.

D. T.Otley, "The contingency theory of management accounting: Society, vol. 5, pp. 413-428, 1980.

E. Anessi-Pessina, G. Nasi, and I. Steccolini, Accounting Reforms: Determinants of Local Governments' Choices vol. 24, 2008.

A. Belal, S. Cooper, and N. Khan, Belal et al CPA 2015, 2015.

R. Kaynak and S. Avci, Logistics Service Accountabilities and their Effects on Service Buyer's Trust vol. 111, 2014.

G. Paulsson, Accrual Accounting in the Public Sector: Experiences From the Central Government in Sweden vol. 22, 2006.

J. Mack and C. Ryan, "Reflections on the theoretical underpinnings of the general-purpose financial reports of Australian government departments," Accounting, Auditing \& Accountability Journal, vol. 19, pp. 592-612, 2006. Achievement and prognosis," Accounting, Organizations and 